Sociohistórica

ISSN: 1852-1606

publicaciones@fahce.unlp.edu.ar

Universidad Nacional de La Plata

Argentina

\title{
Periodistas, criminales y pantallas. El cine policial negro argentino y su relación con la prensa durante el peronismo
}

Giacomelli, Daniel Adrián

Periodistas, criminales y pantallas. El cine policial negro argentino y su relación con la prensa durante el peronismo

Sociohistórica, núm. 46, 2020

Universidad Nacional de La Plata, Argentina

DOI: https://doi.org/10.24215/18521606e109

Atribución no comercial compartir igual (CC BY-NC-SA) 4.0 


\section{Periodistas, criminales y pantallas. El cine policial negro argentino y su relación con la prensa durante el peronismo}

Journalists, criminals and screens. The Argentine film noir and its relationship with the press during Peronism

Daniel Adrián Giacomelli

Facultad de Arte de la Universidad Nacional del Centro de

DOI: https://doi.org/10.24215/18521606e109

la Provincia de Buenos Aires / CONICET, Argentina

daniel.giacomelli1@gmail.com

Recepción: 28 Febrero 2019

Aprobación: 06 Noviembre 2019

Recepción: 28 Febrero 2019

Aprobación: 06 Noviembre 2019

\section{Resumen:}

En el presente artículo nos proponemos analizar tres películas realizadas durante el primer peronismo que dan cuenta del vínculo entre el trabajo periodístico, el Estado y el cine. Indagaremos en la forma en que ciertos elementos de la modernidad urbana inciden en la composición de los filmes, y la manera en la que se ligan a un ciclo específico de la cinematografía mundial como es el cine negro. Mediante el estudio de Apenas un delincuente (Hugo Fregonese, 1949), Edición extra (Luis Moglia Barth, 1949) y Captura recomendada (Don Napy, 1950), intentaremos echar luz sobre la trama establecida entre la prensa y el gobierno de Juan Domingo Perón, considerando aquellos aspectos que incidieron en la tensión entre el autoritarismo y la libertad de prensa y empresa, y el modo en que esos conflictos se ven representados en los films.

Palabras Clave: Cine negro, Estado, Peronismo, Prensa, Representaciones.

\section{Abstract:}

In the present article we propose to analyze three films made during the first Peronism that expose the link between journalism, the State and the cinema. We investigate the way in which certain elements of urban modernity affect the composition of the films, and the way in which they are linked to a specific cycle of world cinematography such as black cinema. Through the study of Apenas un delincuente (Hugo Fregonese, 1949), Edición extra (Luis Moglia Barth, 1949) and Captura recomendada (Don Napy, 1950), we will try to shed light on the thread developed between the press and the government of Juan Domingo Perón, considering those aspects that influenced the tension between authoritarianism and freedom of the press and company, and the way in which those conflicts are represented in the films.

KEYWORDS: Film noir, State, Peronism, Press, Representations.

\section{INTRODUCCIÓN}

Durante el primer peronismo se realizaron una serie de películas dentro del género policial, que abordaban la relación entre la ciudad, el periodismo y el crimen. Los filmes pusieron en el terreno de la trama urbana al periodista como parte del orden social que el gobierno comandado por Juan Domingo Perón promovía. La manera en que el periodista articula la narración de los hechos delictivos en los diarios es presentada en los filmes de maneras diversas, pero en el fondo proponen al trabajador de la prensa como el catalizador de cambios que acompañan a la transformación social de la Argentina. Las películas que exponen la labor de los periodistas lo hacen representando los valores clásicos del periodismo en el contexto de una lucha que se estaba dando a nivel nacional respecto de la tarea comercial o cultural de dicha profesión. En ese sentido, la prensa comercial se vio enfrentada a un Estado que acrecentaba constantemente su influencia sobre los medios.

Por otro lado, los filmes que trabajaremos en estas páginas tienden a manejar la puesta en escena vinculando la realidad histórica con hechos ficcionales. Las reformas impulsadas por un Estado que necesitaba hacerse 
presente en ámbitos de la sociabilidad urbana son atravesadas por el periodismo en los argumentos de las películas, y forman parte del protagonismo de los relatos, en mayor o menor medida, como personajes principales, narradores o como personajes secundarios pero que resultan necesarios para el avance de la narración. Las películas que trabajaremos son Apenas un delincuente (1949) de Hugo Fregonese, Edición extra (1949) de Luis Moglia Barth y Captura recomendada (1950) de Don Napy.

$\mathrm{Al}$ mismo tiempo que representan una visión del trabajo del periodista, las películas también echan luz sobre la modernización de la vida y del delito en la ciudad de Buenos Aires, y del trabajo de las instituciones en esa ciudad y en la vida política de la Argentina. En ese sentido es que las películas presentan la ciudad de Buenos Aires como el escenario de una serie de transformaciones en movimiento desde finales del siglo XIX, e ilustran las tensiones entre la tecnología, la modernidad y la ciudadanía. Por otro lado, estas películas, a pesar de pertenecer a una tradición cinematográfica genérica como es la del policial (incluso en su modalidad de policial negro) responden a la continuidad de una modalidad periodística de gran popularidad desde la década del veinte, como es la del "gran caso".

Si bien la categoría de propaganda no es adecuada para categorizar estos filmes, la manera y el contexto en que fueron producidos no escapan a determinarlos dentro de una lógica en la cual el Estado tenía una considerable influencia en la industria cinematográfica. Es en ese sentido que la Subsecretaría de Información y Prensa comandada por Raúl Apold llevó adelante la producción sistemática de películas documentales, mediometrajes y cortos de ficción, y docudramas destinados a expresar al público los alcances de las políticas sociales del peronismo. Clara Kriger, en relación a los docudramas de propaganda política, menciona:

Desde las instancias de poder se apostó a la construcción de un capital simbólico que otorgara identidad política a la sociedad. Así, el ejercicio del poder político se relacionó, de alguna manera, con la consolidación de ese capital que podía funcionar como eficaz dispositivo de control social (Kriger, 2009. p. 132).

Cuando el peronismo toma el poder en 1946, el cine argentino atravesaba una etapa que fue calificada por los historiadores como periodo clásico-industrial, influido por el desarrollo de productoras cinematográficas que realizaban películas mediante la matriz comercial del sistema de estudios, con una fuerte influencia de los modos de representación institucional hollywoodenses. La impronta genérica fundamental del cine argentino del período clásico-industrial era el melodrama popular, inspirado fuertemente por las letras de tango de las décadas del 20 y los 30. Con la incorporación de técnicas de registro y reproducción de sonido más avanzadas, el cine argentino añadió a su repertorio de géneros y temáticas aquellas provenientes del cine estadounidense; aparecen el policial, el musical, las comedias de teléfono blanco. Estas nuevas maneras de representar conviven con discursos que mantenían un aspecto costumbrista en los elementos de los relatos. Por otro lado, comienza a tomar preponderancia desde finales de la década de 1940 un sesgo social en el cine:

\footnotetext{
comienza a producirse una mayor cantidad de películas que se ocupan del presente y del pasado con intención cognoscitiva y crítica, sin abandonar el modelo narrativo genérico, aunque en muchos casos la intriga sentimental empieza a tener menos peso. A la hora de pensar los motivos que generan este cambio es necesario recordar la segura influencia ejercida por la cinematografía de Occidente, que se vio teñida por una ola de realismo a partir de la posguerra. Razones de diverso orden, desde motivaciones ideológicas hasta innovaciones técnicas (la aparición de cámaras más livianas y películas más sensibles), favorecieron el tratamiento de temas sociales en locaciones reales. De todas maneras, parece evidente que los nuevos elementos temáticos y narrativos surgen en consonancia con un proceso social, político y económico que afectó profundamente la sociedad argentina en esos años (Kriger, 2009, p. 136).
}

\section{EL CINE, EL CRIMEN Y LA INTERPRETACIÓN DE LA REALIDAD A TRAVÉS DE LA PRENSA}

Mabel Tassara (1992) sugiere que el cine policial en Argentina siguió la tendencia genérica del cine negro consagrada en el Hollywood desde los años 40, y expresa que el número de películas que se pueden categorizar dentro del género asciende entre 1947 y 1952. La autora hace énfasis en la manera a través de la cual el género 
pudo ser importado a nuestro país para luego convivir con los modos genéricos locales, lo que dio lugar a expresiones propias del cine policial local:

Puede observarse que es constante la presencia de personajes y situaciones propias de nuestro entorno urbano, sin que se adviertan forzamientos que intenten asimilarlos al cine norteamericano. El policial de ese origen ha ofrecido diversas variantes en lo temático: una suerte de subgéneros, como la guerra de pandillas, la supuesta biografía del delincuente famoso, el film de cárcel, el policial psicológico, el melodrama policial(Tassara, 1992, p. 154).

A diferencia de Kriger, quien propone que desde finales de los 40 el cine argentino aborda temáticas sociales con mayor fuerza, Tassara indica que recién después del peronismo, con filmes como El jefe (1958), de Fernando Ayala, el policial se acercaría a las problemáticas de los colectivos de individuos.

El cine negro estadounidense (canonizado en la tradición crítica como film noir) ha sido desde sus comienzos fuente de debates acerca de su genericidad, y el interrogante acerca de sus orígenes dio lugar a diversas respuestas, que no siempre son unánimes. Dentro de ese debate, Jean-Pierre Esquenazi (2018) considera fundamental, por un lado, la influencia del género gótico en la segunda literatura hardboiled de los años 30 en Estados Unidos, representada por la obra de autores como James Cain y Cornell Woolrich. Esta tendencia es, según Esquenazi, la fuente principal de la estética y tonalidad noir. Por el otro, indica que el estado de ánimo tenso que proveyó el clima de entreguerras y la angustia generalizada posterior a la crisis de 1929 son elementos propios de la ficción negra.

Otros autores, como Carlos Heredero y Antonio Santamarina (1996), amplían el espectro de influencias del noir, teniendo en cuenta las obras literarias previas a las que había hecho alusión Esquenazi, pero incorporando un nuevo factor a la hora de considerar las fuentes: la prensa.

El periodismo se ofrece, entonces, como el tronco común del que nacen en primera instancia (pues no será ésta su única fuente de inspiración) los argumentos de la literatura y del nuevo modelo cinematográfico y, también, de donde proceden algunos de los primeros guionistas del cine sonoro y algunos de los más conocidos novelistas de la serie negra, como James M. Cain, Raoul Whitfield, Horace McCoy, Richard Sale o Jim Thompson (Heredero y Santamarina, 1996, p. 44).

En Argentina, la relación entre prensa y género policial trasciende las barreras del cine y se inmiscuye en la historia de la literatura y el teatro, lo que es comprobable al observar la influencia que tuvo el caso de Juan Moreira en la literatura de Eduardo Gutiérrez. El discurso criollista de la cultura popular argentina tiene como su exponente más representativo la figura de este bandido. A partir de sus representaciones teatrales se encarna en la cultura nacional el valor del coraje y la lucha contra las autoridades ante la imposibilidad de obtener justicia por parte de aquellos que imparten las leyes. Desde la década de 1910 y durante los años 20 el criollismo sería el eje en torno al cual el cine argentino produciría sus obras más representativas. José Agustín Ferreyra representa el paradigma del realizador cuya obra puede ser asociada con un discurso genérico particular (Tranchini, 1998).

Resulta culturalmente significativa la transición que realiza Eduardo Gutiérrez a partir de la escritura de la novela folletinesca Juan Moreira, pues es representativa de dos fenómenos que tienen lugar desde 1880 hasta 1910: la profesionalización del periodista y la profesionalización del escritor (Laera, 2008). A través de sus "Variedades policiales", publicadas en el diario La Patria Argentina desde noviembre de 1879, Gutiérrez comenzó a retratar la vida de los delincuentes más relevantes de su época, introduciendo la temática policial a la manera de los fait divers franceses. El objetivo de Gutiérrez no es narrar casos contemporáneos, sino el relato de casos excepcionales del pasado, como lo fue la historia del bandido Juan Moreira. Con el paso del tiempo las variedades policiales tomarían el nombre de dramas policiales, y con la inclusión de la firma del autor, el folletín adquiriría un carácter más literario. La experiencia de Gutiérrez (junto a otras como las de Roberto Payró y Fray Mocho) da cuenta de que la profesionalización periodística tuvo un lugar preponderante como condición de necesidad de la profesionalización del escritor a finales del siglo XIX, y de cómo la crónica policial se erige como uno de los aspectos fundacionales de la literatura argentina. El caso policial seguirá 
siendo relevante en la relación entre consumos culturales en Argentina durante el período inmediatamente posterior.

Los cambios en la tecnología para la prensa que tuvieron lugar a inicios del siglo XX también implicaron transformaciones no solo en la manera en la que las noticias se distribuían, sino también en cómo se organizaban dentro del periódico y los recursos a través de los cuales se narraban los hechos. Hacia los años 20 y durante la década de 1930

el gran potencial de entretenimiento de las historias del delito se multiplica cuando incluyen imágenes. El dato más decisivo en este desarrollo es la expansión de la fotografía, producto de ciertos avances técnicos: la introducción de la lámpara de flash, que permite mayor velocidad en el obturador, la progresiva transición a la película de acetato, que acelera la velocidad del film, las emulsiones más sensibles y la introducción de cámaras más pequeñas que permiten disparar fotos en serie (Caimari, 2012, p. 62).

La inmediatez de la película fotográfica genera en los fotoperiodistas la inquietud de poder llegar más rápidamente a la escena del crimen y poder capturar el hecho delictivo lo más cercanamente posible a su realización efectiva. La pulsión por acceder a la foto del crimen mismo se vuelve cada vez más intensa, y al no poder lograrlo, las escenificaciones de asaltos, asesinatos, secuestros y atracos comienzan a abundar en los periódicos de Buenos Aires. Las recreaciones de delitos hacen uso de un lenguaje moderno que comenzaba a abundar durante ese período: el cine. La representación del criminal que evocan las noticias pone al pistolero en el centro de la acción, a la manera del protagonista de un film de gánsteres, recuperando así los valores del culto al coraje y la valentía que provenían del criollismo y la gauchesca. Los diarios Abora y Crítica se erigen como los representantes de un tipo de periodismo que media entre los rasgos de la interpretación de la realidad y la construcción de leyendas urbanas sobre el criminal como personaje pintoresco y heroico. Este sesgo fílmico del periodismo delictivo da cuenta de una mundialización del cine y de la construcción de Hollywood como monumento del séptimo arte. Las noticias sobre pistoleros y bandidos, que abundan en los diarios porteños, son contemporáneas al auge del gansterismo en Chicago, cuyo máximo exponente fue $\mathrm{Al}$ Capone, y, al mismo tiempo que su infamia es retratada en la prensa estadounidense, el cine los transpone a la gran pantalla en películas que publicaciones como Heraldo del cinematografista recomiendan para su proyección en salas.

Además, del vínculo entre prensa y cine se desprende un nuevo lazo entre la realidad y el cine. Este ida y vuelta -que va desde el hecho cotidiano de la realidad urbana y del individuo inserto en una sociedad neurálgica hacia los discursos de la prensa que captan una fragmentariedad y la ilustran en los periódicos- es retomado por el cine, que impone una nueva representación, la cual vuelve a los discursos de la prensa, que mecaniza los delitos y los restablece a la sociedad, que inserta nuevamente en la subjetividad del individuo/ espectador/lector el acto criminal a través de un filtro de espectacularidad. Es entonces que cobra fuerza la noción de mímesis, al no trazarse un límite claro entre el hecho delictivo y el lenguaje del entretenimiento cinematográfico. Para la prensa el cine ya no es ajeno a la realidad, sino que el cine es la realidad. La inclusión de la fotografía en los medios masivos de comunicación (y también en el periodismo) estableció una nueva relación entre el individuo y lo noticioso como parte de la sociedad, y el cine ayudó a profundizar ese lazo:

teóricos como André Bazin y Siegfried Kracauer hicieron del realismo supuestamente intrínseco de la cámara la piedra angular de una estética democrática e igualitaria. (...) Para (Rudolf) Arnheim, los defectos del cine (la falta de una tercera dimensión, por ejemplo) eran un trampolín para alcanzar la excelencia artística. Pero lo que para Arnheim debía ser trascendido - la reproducción mecánica del cine de las apariencias fenoménicas- era para Bazin y Kracauer la clave absoluta del poder del cine. Como señaló Bazin (...) "la naturaleza objetiva de la fotografía le confiere una cualidad de credibilidad ausente de cualquier otra forma de creación de imágenes” (Stam, 2001, p. 95).

La tesis de Kracauer sobre el realismo en el cine va aún más lejos. Lleva "la cuestión del realismo a otro plano: la consideración de que las películas representan alegóricamente no la historia literal sino las obsesiones profundas, turbias e inconscientes del deseo y la paranoia nacional" (Stam, 2001, p. 99). Kracauer confía en la posibilidad del cine de destacar de la realidad lo cotidiano, lo azaroso, lo impredecible, el devenir 
de la casualidad. En la Francia de posguerra, la fenomenología de Merleau-Ponty funcionaría como una continuidad del pensamiento de Kracauer, al manifestar cómo las películas muestran las "cosas en sí”, pero afilia al cineasta con el filósofo, al manifestar que los dos llevan a cabo un trabajo intelectual. Las ideas de Merleau-Ponty prefigurarían la filosofía que sobre el cine hace Gilles Deleuze (2011), en cuanto a que la captación de la realidad no se lleva a cabo a través de la continuidad de planos en el montaje, sino a través de unidades mínimas de imágenes-movimiento. Toda imagen en el cine se presenta como una potencia de la realidad, pues es la fragmentación de una duración (en sentido bergsoniano). El montaje reactualiza el movimiento de todo el film generando la idea de una totalidad de duración.

Dentro de las variedades principales de imágenes-movimiento que el filósofo francés reconoce (imagenpercepción, imagen-afección, imagen-acción) hay una categoría que se presenta como especial y que merece ser tenida en cuenta por su correspondencia con lo real: la imagen-pulsión. La pulsión está relacionada, según Deleuze, con un "mundo originario", aquel mundo que no puede ser representado a través de comportamientos o acciones determinadas (intencionadas) de los personajes, o a través del reconocimiento de afectos, y que por ello se transforma -a la hora de ser transpuesto en una obra fílmica- en un "medio derivado". El mundo originario contiene "pedazos", pulsiones que aparecen cuando se desarticulan los comportamientos y los objetos:

el mundo originario no existe ni opera sino en el fondo de un medio real, y no vale sino por su inmanencia a este medio cuya violencia y crueldad él revela; pero, además, el medio no se presenta como real más que en su inmanencia al mundo originario, tiene el estatuto de un medio «derivado» que recibe del mundo originario una temporalidad como destino. Es preciso que las acciones o los comportamientos, las personas y los objetos, ocupen el medio derivado y se desarrollen en él, mientras que las pulsiones y los pedazos pueblan el mundo originario que arrastra con todo (Deleuze, 2011, p. 181).

Esto se refleja, afirma Deleuze, en la violencia naturalista del cine de Stroheim y Buñuel, y podemos intuir que esta -que en el fondo es pulsión de muerte- es una variedad particular de imagen-movimiento característica de la violencia del cine policial y de gánsteres de los 20 y 30. Es a través de esa imagen-pulsión que la noticia criminal se reactualiza y disemina imaginarios en la sociedad. La pulsión violenta en la crónica del crimen se ve ilustrada ostensiblemente en la prensa de cambio de siglo, que se insertaba cada vez más profundamente en una modernidad neurológica cargada con -si seguimos a Simmel (2005) - un exceso de estimulación nerviosa. La experiencia subjetiva se ve modificada por los diversos shocks que las grandes metrópolis ejercen en el individuo. En ese contexto, "la prensa ilustrada ofrece una huella particularmente rica de la fijación de la cultura sobre los asaltos sensoriales de la modernidad" (Singer, 1995, p. 75).

La prensa de las grandes urbes estadounidenses -New York, Chicago, Los Angeles- solía ilustrar las muertes de los transeúntes que se enfrentaban al tráfico de trenes, tranvías y automóviles, maquinarias que aún no resultaban conocidas por la mayoría de la población. Abundan las imágenes de los momentos exactos en que los caminantes son impactados por los vehículos, así como las caídas desde alturas y edificios, y los accidentes de trabajo. Este tipo de noticias, así como las crónicas delictivas que los diarios de Buenos Aires presentan, refleja "las ansiedades de una sociedad que aún no se había adaptado completamente a la modernidad" (Singer, 1995, p. 88)

El cine culmina esa tendencia hacia la espectacularidad y la magnificación de los hechos, en un entorno en el que el sujeto lector/espectador está rodeado de estímulos visuales y sonoros que no llega a desentrañar completamente. El máximo ejemplo de este tipo de individuo lo conforma Roberto Arlt, quien en sus columnas para el diario El Mundo -que posteriormente se transformarían en sus "Aguafuertes porteñas-"dedicó varias líneas a la relación que tuvo el cine con su subjetividad, la de un sujeto urbano interesado en las innovaciones de su época.

El cine es una actividad distinta a la flanería urbana -que aquí aparece consignada como "vagabundeo"-, sin embargo, la complementa. El cine es lo que -en términos derrideanos- excede y lo que hace falta al acto de vagabundear: su suplemento, es decir lo que se hace antes y además de recorrer la ciudad” (De los Ríos, 2009, pp. 464-465). 
Arlt se presenta con una doble funcionalidad, la de periodista y espectador, y no deja de mantener unidas las dos actividades. El cine como experiencia cosmopolita lo hace formar parte de una comunidad imaginada de espectadores que encuentran en el cine el sosiego ante una urbe que los aliena, y deciden olvidar sus problemas frente a las pantallas. Arlt lleva esta manera de vivir en la modernidad a las páginas con claridad:

De lo que no me queda ninguna duda es que el cine está creando las modalidades de una nueva psicología en el interior. ¿Qué resultado tendrá ello? No lo sé, pero abrigo la seguridad que son numerosas las muchachas que una tarde de domingo, en estas ciudades de provincias, al salir del cine se dicen: "-No, así no se puede seguir viviendo. Hay que tratar de resolver esto" (Arlt, 1997, p. 111).

El cine construye para Arlt un modelo de espectador que no manifiesta una distancia entre lo que tiene lugar en la pantalla y lo que sucede en las calles de la ciudad. Se plantea una mímesis entre el sujeto espectador y el sujeto urbano, y el cine negro en Argentina daría cuenta de ese fenómeno.

\section{El PERiodista como agente del Estado}

Pocas secuencias en el cine argentino hacen alusión al vínculo entre el cine, el periodismo y la vida en las ciudades como el inicio de Apenas un delincuente (1949) de Hugo Fregonese. Al comenzar la cinta advertimos la presencia de un auto que atraviesa la pantalla a toda velocidad, al poco tiempo observamos los coches, que por el sonido que emiten no pueden ser otros que automóviles de patrulla policial. Tras una serie de disparos entre los policías y el auto que persiguen, este vuelca sobre el terraplén de un camino y se prende fuego. Mediante una técnica de montaje, el encuadre en el cual se puede vislumbrar el coche incendiándose y los policías observando la escena se transforma en la foto de una portada de un diario, que incluye el titular "Capturan herido a josé morán. Varios Policías Muertos en la Refriega”. La foto representa el instante inmediato en que sucede el accidente y la inmediata llegada de la policía a la escena. No se muestra ninguna mediación de fotógrafo, el periódico captura el momento, incluye una nota, agrega un título, una bajada y notas accesorias. El plano se funde con otro que muestra las rotativas imprimiendo el nuevo número del diario, e instantáneamente vemos las manos del editor de la publicación que se acerca a un intercomunicador y se contacta con Crespo, un redactor, a quien le solicita que inicie una nota sobre José Morán.

Allí comienza una nueva secuencia en la cual se observa a Crespo ir a buscar datos sobre José Morán en los archivos del periódico. En la escena siguiente vemos el contenido del archivo: fotos, documentos, notas; Crespo comienza a redactar en su máquina de escribir. Inicia una sucesión de imágenes que funcionan a la manera de una "sinfonía de ciudad" ${ }^{2}$ en la cual se suceden tomas aéreas de Buenos Aires a la mañana, acompañadas de otras en las cuales se observan las calles vacías antes de la llegada de los trabajadores y los transeúntes. Tomas en ángulos aberrantes de trenes, tranvías, colectivos a altas velocidades, estaciones colmadas de pasajeros que bajan y suben de vehículos se suceden vertiginosamente. Sobre la imagen de vehículos y personas atravesando grandes avenidas oímos a Crespo anunciar en off que "Esta es la ciudad de los nervios excitados..." Continúan las tomas de personas caminando apresuradamente, los planos detalle de manos que se prenden a bocinas, volantes, manubrios y asideros. La voz off de Crespo hace énfasis repetidamente en el "el apuro, el apuro...", y no repara en ningún rostro, hasta hacer énfasis en José Morán, quien camina velozmente a contramano de la masa de personas que circula por la misma vereda. Crespo dice que Morán es "el más impaciente de todos". La imagen se congela por unos segundos sobre el plano de Morán cruzando la calle mientras el resto de los caminantes lo mira perplejamente. "Entremos en su vida" es la invitación que realiza Crespo para comenzar a dar fin a la narración inicial, mientras comenta que para Morán -a quien vemos jugando a las cartas en lo que parece ser el sótano de una boîte- el dinero es lo más importante en su vida, y que el juego es la "ganzúa" mediante la cual querrá saltarse pasos.

El film luego contará el relato de cómo Morán estafa a su empresa para quedarse con una suma ilegal de dinero, la cual esconderá y esperará a salir de la cárcel para ir a buscarla. Nos interesa dejar claro el modo 
en el que el periodismo articula la vida en la ciudad, el crimen y el cine a través del montaje de las primeras secuencias de la película: la narración hace alusión a los "nervios excitados" -la hiperestimulación nerviosa que mencionaba Georg Simmel ya en 1905-, acentuados por la necesidad de llegar a los lugares de trabajo para conseguir remuneración monetaria. El relato de la corrupción moral de Morán ayuda a poner de manifiesto en el film el rol regulador de la prensa en el Estado peronista. Y qué mejor manera de exponerlo que a través de la concatenación de imágenes-pulsión que conectan directamente con ese "mundo originario" de los deseos e impulsos incontrolables. Que la narración sea llevada a cabo por un periodista ayuda a expresar los deseos de un Estado que considera que el paso del individuo por las instituciones debe ser reflejado por la prensa, y, en ese sentido, no es menor la influencia que tuvo la Subsecretaría de Información y Prensa durante el período histórico en el que se contextualiza la producción del film.

Si bien hemos mencionado que dicha subsecretaría se dedicaba a producir ciertos tipos de obras audiovisuales (cortometrajes documentales y docudramas), la política cultural del peronismo puso en marcha la censura a través de la Dirección General de Espectáculos Públicos -dependiente de la Subsecretaría-, que desde el año 1945 se encontraba intervenida. Hacia 1949 la situación comenzó a cambiar sostenidamente, gracias a la figura de Raúl Apold, quien se encontraba a la cabeza de la Subsecretaría desde marzo de ese año: "Además de mantener los viejos pruritos hacia films que mostraban la vida nocturna, se inició un proceso de coacción sobre aquellas películas que abordaban la historia argentina generando versiones críticas y alternativas de los sucesos." (Kelly Hopfenblatt y Trombetta, 2009, p. 261) De ese modo, Apenas un delincuente contó con censura oficial, y debió ser incluida una leyenda al comienzo de la película que rezaba: "Esta es una historia de la ciudad. Sucedió, o pudo suceder hace varios años... Entonces, las cárceles no eran como ahora... Y por un resquicio del código se filtró la idea de un delito audaz..."

Apenas un delincuente forma parte de un subgénero del policial negro denominado policial en las calles $^{3}$ (Kriger, 2009), al cual también pertenecen filmes realizados por Don Napy (Captura recomendada, Camino al crimen, Mala gente) y Kurt Land (Mercado negro, La delatora). De todos ellos, Captura recomendada (1950) es el que plantea un vínculo manifiesto entre la prensa y la lucha contra el crimen. Al comienzo del film tiene lugar una ceremonia de premiación a oficiales de policía, a la que acude un joven e inexperto periodista anónimo para cubrir las novedades. Allí se encuentra con un veterano de la profesión (perteneciente al diario La Razón), que le presenta al resto de los periodistas que cubren el evento. Para volver más difusos los límites entre ficción y documental, se presentan frente al joven periodista una serie de trabajadores de la prensa que nombran sus proveniencias (Agencia TELAM y ANA, diario Crítica, Noticias Gráficas, La Razón). Seguidamente ingresa a la sala el inspector Campos, ${ }^{4}$ uno de los policías galardonados esa noche. Campos es presentado al joven periodista, y comienzan a tener una charla que habilita a que el film inicie una serie de flashbacks mediante los cuales Campos relata sus momentos más importantes como parte de las fuerzas del orden. Las tres narraciones que forman parte del film ayudan a exponer la entonces innovadora tecnología con la que contaba la Policía Federal. Cada vez que finaliza un flashback, la acción vuelve a situarse en la sala donde Campos está reunido con el periodista, y, mientras avanzan los relatos, se establece una complicidad mayor entre el trabajador de la prensa y el inspector de policía.

Si bien no se sabe en qué medida el Estado influyó en la realización de este film, probablemente el autoritarismo de la Subsecretaría de Prensa y Difusión en cuanto a los valores promovidos se haya impregnado en la producción. La manera en la que se manifiesta la presencia del Estado pareciera responder a una propaganda de las instituciones. Captura recomendada forma parte de una serie de películas que

ponen en pantalla a una sociedad que se ve afectada por las acciones delictivas y un estado que intenta mediar, reparar, articular las formas posibles de resolución de conflictos. Es decir que instalan los conflictos privados de los personajes en la esfera de lo público, en un espacio de debate en el que estas instituciones estatales parecen tener un rol relevante. (...) Es posible pensar que estas producciones simbólicas tienden a reforzar y legitimar el poder del estado al promover la imagen de un estado moderno que, mientras protege a la comunidad, castiga y educa adecuadamente a quienes violan la ley. (...) En el epílogo de Captura recomendada se ve un primer plano del inspector Campos, de frente a la cámara, quien le habla 
directamente al espectador, rompe la ilusión ficcional y apela a una relación actualizada entre la institución policial y el ciudadano (Kriger, 2009, pp. 145-146).

Del mismo modo, la película integra al periodista al Estado al exponer progresivamente la relación entre el inspector Campos y el joven trabajador de la prensa. La misma relación actualizada entre la policía y el ciudadano involucra al periodismo, que funciona como los oídos y los ojos del Estado, y, por lo tanto, de las fuerzas del orden. Ante la sociedad, la policía y la prensa forman parte del mismo orden y cumplen una función conjunta de control, castigo y regulación de la opinión pública. El modelo de Estado que propone la película se conjuga con la nueva relación entre Estado y sociedad civil que comenzaría a desarrollarse desde el golpe militar de junio de 1943 y a través de todo el peronismo.

\section{EDICIÓN EXTRA Y LA GUERRA CON EL "CUARTO ENEMIGO”}

La finalidad inicial del proyecto de la Secretaría de Información y Prensa del gobierno de oficiales del GOU había sido "facilitar un fluido y no distorsionado flujo de comunicación desde un gobierno militar privado de una base política organizada hacia el público general y guiarlo hacia una visión favorable del nuevo gobierno"5(Cane, 2011, p. 95). De esta manera se difuminaba la relación entre prensa y Estado, al querer este último establecer una hegemonía a través de los diarios de tirada masiva en Buenos Aires. En ese sentido, uno de los principios fundamentales de la prensa liberal quedaba vedado.

Desde ese entonces los diarios más importantes de Buenos Aires comenzaron una relación tensa con el nuevo orden, que se mantendría hasta entrado el ciclo peronista. Progresivamente los editoriales de periódicos como La Prensa y La Nación emprenderían una campaña denostando los objetivos intervencionistas del gobierno de facto. La respuesta de las autoridades de la dictadura fue la elaboración de un decreto que indicaba que la prensa no era una mera actividad cultural, sino que perseguía al mismo tiempo un fin económico, lo que la convertía también en una actividad comercial. En consecuencia, el nuevo gobierno a través de la Secretaría de Trabajo y Previsión Social comandada por Juan Perón- apoyaría el reclamo de los trabajadores de la prensa, a través de la firma del Estatuto del Periodista de 1944, que aseguraba una mejora económica y beneficios para todos aquellos que eran empleados por los grandes diarios. La iniciativa de Perón colocó el conflicto de clases dentro de las redacciones de los periódicos de Buenos Aires al tomar en cuenta al periodista como miembro de la clase trabajadora.

Como respuesta, el diario La Prensa se manifestó abiertamente en contra de la nueva regulación, y expresó que el Estatuto del Periodista convertiría a la Argentina en un país abiertamente totalitario. La decidida oposición del periódico ante el gobierno militar, y más expresamente frente a la figura de Perón, llevaría a un continuo escenario de conflicto entre La Prensa y el Estado. A la acusación de La Prensa de que el Estado autoritario ponía trabas a la libertad de prensa y de empresa se sumaba el descontento por parte de los medios con un gobierno que presentaba rasgos cuestionables. Todo esto se dio en un contexto internacional de posguerra que repudiaba enérgicamente aquellos aspectos que ligaran al peronismo a un autoritarismo filofascista. La Prensa junto con los periódicos comerciales restantes se nuclearon dentro del manifiesto de las "Fuerzas vivas", en el que expresaban su desavenencia con las políticas laborales de la secretaría liderada por Perón, y con el autoritarismo censor del gobierno dictatorial. Este alineamiento no hizo más que polarizar la opinión pública:

esta creciente brecha entre "prensa” y "público”, así como las demandas populares de representación en las páginas de los “órganos de opinión”, colocaría a Crítica, el periódico cuya larga demanda de encarnar el sentimiento popular se volvería repentina y sorprendentemente sin sentido, literalmente en la mira de las fuerzas pro-Perón (Cane, 2012, p. 163).

Al culminar el ascenso de Perón, durante los eventos del 17 de octubre de 1945 un grupo de activistas peronistas acudieron a las oficinas de Crítica e ingresaron a destruir imprentas y máquinas, lo que terminó con un saldo de dos muertos y treinta y seis heridos. 
Luego del fin de la guerra se profundizó una crisis en la provisión de papel para impresión de periódicos, en la cual el Estado tomó la decisión de intervenir confiscando material de impresión de diarios como La Prensa, La Razón y La Nación. A esta situación se sumó la sanción de un nuevo decreto, que establecía reformas en el Estatuto del Periodista y aumentaba la presión fiscal sobre los dueños de los periódicos. Esta situación fue aprovechada posteriormente por Perón para apropiarse de los más importantes diarios de Buenos Aires. En una primera instancia un salvataje por parte del Banco Central hacia finales de 1946 permitió que el gobierno pudiera controlar La Razón y, tras un largo y complejo procedimiento legal, los herederos de Natalio Botana cedieron Critica a un grupo de inversores peronistas en febrero de 1947.

La contienda con La Prensa merece especial atención, pues tiene lugar durante la producción de Edición extra, film estrenado en 1949. Luego de ubicarse del lado del sindicato de canillitas -quienes reclamaban que el periódico finalizara su servicio de suscripción autofinanciado, ya que al ser el diario más vendido no permitía que los canillitas recibieran ganancias de sus ventas- el gobierno acompañó un boicot a La Prensa, al que le siguió la acusación del resto de diarios controlados por los peronistas, que indicaban que "Los periódicos de la oposición, principalmente La Prensa, eran descriptos como 'antiamericanos', 'oligárquicos' e incluso políticamente traidores" (Cane, 2012, p. 214). La disputa con los canillitas evolucionó en una huelga, a la que se unió la CGT en enero de 1951, y siete semanas después, una comisión enviada por la Cámara de Diputados de la Nación investigó los libros financieros de La Prensa. Allí encontró que su dueño, Alberto Gainza Paz había evadido impuestos, lo que convertía al periódico no solo en una institución comercial, debido a sus ingresos por publicidad, sino en una que al mismo tiempo se encontraba infringiendo la ley. Por una amplia mayoría el Congreso votó a favor de la expropiación de la empresa de la familia Paz, y logró que pasara a manos del ejecutivo.

La manera en la que este conflicto aparece reflejado en Edición extra es a través de nombres ficticios, pero que permiten establecer analogías con eventos, personas e instituciones de la realidad contemporánea. El film cuenta la historia de Alberto Giménez, un periodista del diario La Crónica, que investiga el asesinato del diputado Martín Barrera, quien estaba a punto de pronunciarse en contra de una ley que perjudicaría a la economía argentina, al permitir que capitales extranjeros se aprovecharan de la industria agrícola. Giménez se incorpora al argumento como un periodista ambicioso y con deseos de ascenso social, asociados a la capacidad del periódico para el que trabaja de crear relatos sensacionalistas que no cuentan la verdad sobre los hechos sucedidos. Al avanzar la película, Giménez comienza a descubrir cómo Linares, el editor del diario, lo obliga a tergiversar información esencial para el avance del caso, como, por ejemplo, el descubrimiento de veneno en el cuerpo de Barrera. Este tipo de revelaciones hacen que Giménez deje su trabajo en La Crónica para investigar la causa por su cuenta. Así es que Giménez se convierte en un detective hardboiled. Eventualmente descubre la trama secreta detrás del asesinato de Barrera: los empresarios que llevaron a cabo el plan para envenenar a Barrera también habían puesto en marcha una campaña de difamación contra el diputado, mediante la cual lo vinculaban a prostitutas y establecimientos de juego ilegal. Hacia el final del film el relato nos ubica en la Cámara de Diputados de la Nación; allí, uno de sus miembros explica cómo la ley beneficiaría a los intereses extranjeros por culpa de una "mayoría vendepatria". Sin embargo, luego de la sesión, la ley es rechazada.

La película se inspira en un hecho sucedido en 1926, pero asegura mediante una placa al inicio -como lo había hecho el mismo año Apenas un delincuente- que los sucesos del film no podrían acontecer en la nueva Argentina que se estaba gestando entonces: "refleja un momento de la vida del país, afortunadamente lejano pero que cuya lección no debe olvidarse”. Como el film de Fregonese, Edición extra pareciera tener un fin didáctico para la población, sin embargo, recibió críticas de parte del Sindicato Argentino de Prensa por exponer una visión amarillista del trabajo de los periódicos (Blanco Pazos y Clemente, 2004, p. 88). Nuevamente se presenta en una película al periodista como un trabajador en pos de la consagración de ideales de la libertad de la prensa, aunque en consonancia con la idea de un Estado tutelar, de la misma manera que sucede con el periodista de Captura recomendada. En ese sentido, la búsqueda de la verdad no se presenta solo como una tarea a cumplir por motivos personales, sino con base en el rechazo a una ley que iría en contra 
de los valores patrióticos: el periodista se asume a sí mismo como un agente del Estado. Por otra parte, la película no es muy sutil para expresar el conflicto que contemporáneamente tenía lugar entre el Estado y los periódicos, el diario La Crítica es una clara alusión a La Prensa, como se manifiesta a través del edificio, que se asemeja en gran parte al de la empresa de la familia Paz, con su nombre en la cima de la fachada.

Se deja entrever en la película una doble finalidad: presentar al periodista como un trabajador que forma parte de un Estado moderno y protector, al tanto de los intereses del resto de los miembros de su mismo colectivo, y, al mismo tiempo, exponer los peligros de la prensa como actividad puramente comercial, en tanto que su actividad económica va en detrimento de los intereses de la mayoría, y en beneficio de una minoría oligarca y vendepatria.

\section{Conclusiones}

Las películas que hemos estudiado dan cuenta de la influencia de los discursos periodísticos en la consolidación de un género cinematográfico de gran relevancia como fue el cine negro durante el período clásico-industrial. El desarrollo de este género va de la mano de transformaciones en las ciudades y en sus instituciones y habitantes. Dichas transformaciones tienen lugar en el punto más álgido de la modernidad de aquel momento, en el que discursos como el cine y los avances en la tecnología de los medios de comunicación acentuaban la vertiginosidad cotidiana. El cine como parte de la realidad sumerge al sujeto espectador/lector en un remolino de mensajes y estímulos, en el que se mezclaban las pugnas entre los fines reguladores de la opinión pública por parte del gobierno peronista y la avasalladora actividad comercial de la prensa. Así es que el Estado ingresa en ese contexto crítico con la convicción de imponer su fuerza.

El noir funciona como una herramienta que permite exponer diferentes versiones del trabajo periodístico en las grandes ciudades durante el peronismo. En Apenas un delincuente queda manifiesta la relación entre la violencia urbana, la ansiedad y la hiperestimulación como bases para la corrupción del individuo en contra del colectivo. La imagen-pulsión deleuziana narra de la manera más adecuada el espíritu del antihéroe que protagoniza la película y prefigura el destino de José Morán. A la vez, el film culmina el trayecto que la prensa había iniciado, al utilizar el lenguaje audiovisual como la mejor forma de manifestar la vertiginosidad de las ciudades, y al permitirse ubicar al periodista como el motor del argumento.

Captura recomendada ubica en la misma instancia el trabajo del periodista con el del integrante de las fuerzas del orden, buscando la armonía entre la prensa y la policía. En ese sentido, el trabajador de la prensa es parte del Estado, con sus mismas responsabilidades y deberes. La película expone una utopía donde las fuerzas del orden realizan su deber y los miembros de todas las agencias e instituciones periodísticas complementan la tarea de vigilancia, ordenamiento e interpretación de la opinión pública. En términos de condiciones de producción, la obra cuenta con los parámetros que la Secretaría de Información y Prensa liderada por Raúl Apold consideraba adecuados para la promoción de valores nacionales y la reivindicación del espíritu del peronismo.

Edición extra problematiza la capacidad de la prensa de incorporarse al orden de un modelo de Estado que lleva a cabo una transformación profunda de los valores fundamentales de esa profesión. Expone los peligros de la prensa comercial para los intereses nacionales mediante un relato que permite leer entre líneas el conflicto entre el autoritarismo peronista y el diario La Prensa. En ese sentido, la película reivindica la tarea del periodista, como exponente de la clase trabajadora que puede acoplarse a los fines de un Estado protector, al resolver un asesinato por convicciones personales que se conjugan en la defensa de un colectivo, y no con el fin de que su labor acabe convirtiéndose en una nota que responda a la tendencia comercial del periódico. En un movimiento poco habitual en el cine argentino, Giménez muta en detective hardboiled dispuesto a descubrir la verdad detrás del crimen.

El análisis de estos tres filmes ayuda a echar luz sobre las transformaciones sociales, culturales, políticas y laborales de la Argentina de mediados de siglo XX, al presentar las tensiones entre Estado y prensa. El 
interés de estos filmes por reflejar los procesos detrás de la construcción de la opinión pública manifiesta la voluntad de parte de sectores estatales de formar una comunidad de espectadores que -al mismo tiempo que disfrutan las películas- emerjan de las salas con la noción de que son componentes esenciales de un proceso de transformación nacional. Las películas que hemos analizado forman parte de un contexto en el que "Perón había reemplazado las vibrantes industrias culturales capitalistas por un vasto dispositivo designado para servir a los intereses del Estado" (Karush, 2013, p. 227). Cada decisión artística en el campo de la producción cinematográfica estaba sujeta al control político, y, en ese sentido, Apenas un delincuente, Edición extra y Captura recomendada ponen de manifiesto los mecanismos a través de los cuales el Estado incide en los medios, tanto en el cine como en la prensa.

\section{REFERENCIAS}

Arlt, R. (1997). Notas sobre el cinematógrafo. Buenos Aires: Ediciones Simurg.

Blanco Pazos, R. y Clemente, R. (2004). De La Fuga a La Fuga. El policial en el cine argentino. Buenos Aires: Corregidor.

Borde, R. y Chaumeton, E. (1958). Panorama del cine negro. Buenos Aires: Losange.

Caimari, L. (2012). Mientras la ciudad duerme. Pistoleros, policias y periodistas en Buenos Aires, 1920-1945. Buenos Aires: Siglo Veintiuno.

Cane, James (2012). The Fourth Estate. Journalism and Power in the Making of Peronist Argentina, 1930-1955. The Pennsylvania State University Press.

De los Ríos, V. (2009). El cine y la invención de la vida moderna en las crónicas de Roberto Arlt. En Modern Language Notes (124) (pp. 460-480). Baltimore: John Hopkins University Press.

Deleuze, G. (2011). La imagen-movimiento. Estudios sobre cine 1. Barcelona: Paidós.

Esquenazi, J.P. (2018). El film noir. Buenos Aires: El Cuenco de Plata.

Heredero, C. y Santamarina, A. (1996). El cine negro. Barcelona: Paidós.

Karush, M.B. (2013). Cultura de clase. Radio y cine en la creación de una Argentina dividida (1920-1946). Buenos Aires: Ariel.

Kelly Hopfenblatt, A. y Trombetta, J. (2009). Características de la censura entre 1933 y 1956. Continuidades y rupturas de la identidad nacional. En Lusnich, A.L. y Piedras, P. (Eds.) Una historia del cine politico y social en Argentina (1896-1969) (pp. 251-267). Buenos Aires: Nueva Librería.

Kriger, C. (2009). Cine y peronismo: el Estado en escena. Buenos Aires: Siglo Veintiuno.

Laera, A. (2008). Cronistas, novelistas: la prensa periódica como espacio de profesionalización en Argentina (1880-1910). En Altamirano, C. (Ed.) Historia de los intelectuales en América Latina: Vol. 1. (pp. 495-522) Buenos Aires: Katz

Simmel, G. (2005). La metrópolis y la vida mental. Bifurcaciones. Revista de estudios culturales urbanos. (4) (s/n)

Singer, B. (1995). Modernity, Hyperstimulus, and the Rise of Popular Sensationalism. En Charney, L. y Schwartz, V.R. (Eds.) Cinema and the Invention of Modern Life (pp. 72-99). Berkeley: University of California Press.

Stam, R. (2001). Teorias del cine. Buenos Aires: Paidós.

Tassara, M. (1992). El cine policial Argentino. En Wolf, S. (Ed.) Cine Argentino. La otra historia (pp.147-167). Buenos Aires: Colihue.

Tranchini, E. (1998). El Cine Argentino y la construcción de un imaginario criollista 1915-1945. Entrepasados. Revista de historia. (18/19), pp. 113-141.

\section{Notas}

1 En la obra de Arlt 
Daniel Adrián Giacomelli. Periodistas, criminales y pantallas. El cine policial negro argentino y ...

2 Nos referimos a films como Berlin: Die Sinfonie der Großstadt (1927) de Walter Ruttmann, Regen (1929) de Joris Ivens, y algunos aspectos de Человек с кино-аппаратом (El hombre de la cámara) de Dziga Vertov, estrenada en 1929.

3 Este subgénero deriva de lo que Borde y Chaumetón (1958) dieron en llamar documental policiaco.

4 El personaje de Campos provenía del programa de radio Ronda policial, interpretado por Eduardo Rudy, quien vuelve al rol para la película que analizamos.

5 La traducción es nuestra.

\section{BY-NC-SA}

